\title{
Chapter 6 \\ Water Use and Yield of Millet Under the Zai System: Understanding the Processes Using Simulation
}

\author{
Dougbedji Fatondji, André Bationo, Ramadjita Tabo, James W. Jones, \\ A. Adamou, and O. Hassane
}

\begin{abstract}
In the drylands of Africa about $90 \%$ of the population is rural and depends on subsistence agriculture for their livelihoods. There is an increasing pressure on the natural resources due to the high population growth, and farmers are constrained to cultivate marginal lands, thereby compounding the land degradation problem. Low and erratic rainfall, its poor distribution within the growing season, prolonged dry spells, lack of adequate water supply due to soil physical degradation (soil crusting) and nutrient shortage adversely affect crop growth and yields. To address these problems, indigenous, easy to implement innovations such as the zai system may provide solutions to increase productivity. The effect of three planting techniques (Flat, zai pit of $25 \mathrm{~cm}$ and zai pit of $50 \mathrm{~cm}$ diameter) and three fertility management options (control, crop residue, cattle manure) were tested at Damari in 1999 in Niger. Soil water was monitored from weekly measurements using a Didcot
\end{abstract}

D. Fatondji $(\bowtie) \bullet$ A. Adamou $\bullet$ O. Hassane

Soil \& water management, International Crop Research Institute for the Semi-Arid Tropic,

P.O. Box 12404, Niamey, Niger

e-mail: d.fatondji@cgiar.org

A. Bationo

Soil Health Program, Alliance for a Green Revolution, in Africa (AGRA), Agostino Neto Road, Airport Res. Area 6 Accra, PMB KIA 114, Airport-Accra, Ghana

e-mail: abationo@agra-alliance.org

R. Tabo

ICRISAT Niamey, P.O. Box 12404, Niamey, Niger

Forum for Agricultural Research in Africa (FARA), Accra, Ghana

e-mail: rtabo@fara-africa.org

J.W. Jones

Agricultural and Biological Engineering Department, University of Florida,

Gainesville, FL 32611, USA 
Wallingford neutron probe throughout the growing period. Data from that experiment were used to determine if the CERES-Millet model of the Decision Support System for Agrotechnology Transfer (DSSAT) is sufficiently robust to predict yield response to the zai water harvesting system. The model simulated the observed yield response of the control and the manure-amended plots with high r-square (0.99), low residual mean error square $\left(340 \mathrm{~kg} \cdot \mathrm{ha}^{-1}\right.$ for above ground biomass and $94 \mathrm{~kg} \cdot \mathrm{ha}^{-1}$ for grain yield) and high d-statistic (0.99), but this was not the case for the crop residue treatment, which was over-predicted. Soil water content and extractable soil water were also well simulated for the control and manure treatments. This evaluation of DSSAT provides a starting point for research to evaluate the performance of these technologies over wider areas in West Africa. The application of models for such studies must be interpreted in the context of limitations of the model to address some constraints. Nevertheless, the highly variable crop responses due to interacting effects of rainfall, management and adverse soil conditions in this region make this an extremely important approach in planning for technology adoption in an area and in interpreting results from experimental field research.

\section{Keywords Zai $\bullet$ DSSAT $\bullet$ Simulation $\bullet$ Damari $\bullet$ Water haversting}

\section{Introduction}

In the dry lands of Africa, about $90 \%$ of the population is rural and depends on subsistence agriculture for their livelihoods (Bationo et al. 2003). Low and erratic rainfall, its poor distribution within the crop growing period, prolonged dry spells, lack of adequate water supply due to soil physical degradation (soil crusting, low water retention) and nutrient shortage often adversely affect crop growth and yields in this zone (Zougmoré et al. 2003). According to Sundquist (2004) desertification along the Sahara desert proceeds at an estimated $1,000 \mathrm{~km}^{2}$ every year, which further increases the pressure on arable land. One reason for this is the mounting population pressure (3\% yearly growth on average) and the limited availability of fertile land. Many researchers have studied a wide range of management practices for increasing productivity, including testing of better adapted varieties, use of inorganic and organic fertilizer (Buerkert et al. 2002; Schlecht et al. 2004; Bationo et al. 1995; Yamoah et al. 2002; Tabo et al. 2007), rotation and residue management (Bado et al. 2007; Fatondji et al. 2006; Adamou et al. 2007) and water harvesting methods (Agyare et al. 2008; Roose et al. 1993).

One of the techniques studied is the zai system, an indigenous technology that combines rain water collection (Roose et al. 1993; Fatondji 2002), and nutrient management. Research has shown that the zai technology promotes crop production on highly degraded soils and helps alleviate the adverse effects of dry spells, which are frequent during the cropping period in the Sahel (Roose et al. 1993; Hassan 1996; Fatondji et al. 2006). This results not only from soil fertility improvement derived from the applied amendment and wind-driven materials that collect in the pits, but 
also improvement of the soil water status following the breakage of the surface crust and higher water infiltration (Fatondji 2002). Applying the zai technology on crusted soils results in rapid progress of the soil wetting front, which may drain to deeper layers to recharge ground water and also leach nutrients (e.g., nitrates Fatondji et al. 2011). Depending upon soil and crop growth conditions, the proportion of drained water is variable. Using the zai system or other soil and water conservation techniques for crop production may improve productivity and help eliminate hunger in the dry land of West Africa. However soil type, climate and other conditions vary over time and space and influence the ways those technologies interact.

Because many studies do not collect enough data to understand the interactive effects of soil and weather conditions that affect crop yield, it is difficult to extrapolate results from specific experiments to other soil and weather conditions. Crop simulation models deal with these interactive effects and have been used to predict how crop technologies will perform across sites and seasons and may help develop better management techniques for a wide range of conditions. However, it is not clear that the models are suitable for predicting crop performance under the degraded soils and extreme climatic conditions of West Africa. Although models have been used in many studies in Africa, they usually take into account only one or two limiting factors, such as variable rainfall and fertilizer input. Degraded soils have a number of factors that interact to limit crop growth and yield in complex ways. In order to use crop models for those conditions, they need to be tested in experiments in which measurements are made to provide all of the needed soil parameters, weather conditions, initial soil condition, management inputs and soil and crop growth responses. If the models are successful, they can be used to predict performance of the technologies and reduce the need for expensive and time-consuming field experimentation across regions.

Crop models in the Decision Support System for Agrotechnology Transfer (DSSAT) (Tsuji et al. 1994; Jones et al. 2003) have been used widely worldwide. This modeling system was designed for users to create computer experiments, simulate outcomes of the agricultural practices, soil, and weather conditions, and suggest appropriate solutions for specific sites (Jones et al. 1998). The millet model (CERESMillet; Singh et al. 1991), like other models in DSSAT, is designed to be independent of location, season and management since it simulates the effects of weather, soil water, cultivar, and nitrogen dynamics in the soil on crop growth and yield. This model has not been evaluated for simulating production using zai technologies.

An experiment was conducted on a farmer's field at Damari in Niger (West Africa) to evaluate management systems that would increase yield and water productivity of millet (Fatondji et al. 2006). The overall objective of that work was to study the productivity and resource use efficiency of millet under rainfed conditions in the zai system as compared to flat planting on a highly degraded soil. In this study, we used data from that experiment to determine if the CERES-Millet model is sufficiently robust to predict yield response to the zai water harvesting system. This experiment was selected because of the potential importance of the zai system in the Sahel which has highly degraded soils and because an intensive set of data was collected on soil physical and chemical conditions, daily weather, weekly volumetric soil water versus depth, and crop yield and biomass productivities. The soil 


\section{Editor's Proof}

and climate conditions of this site challenge the capability of crop models because of the extreme soil physical and chemical properties and intensive rainstorms. The low soil water holding ability, soil crusting, low organic carbon, variable quality of organic amendments, low fertility, low $\mathrm{pH}$ and intensive rainfall events, when combined, may stretch the limits of crop models beyond their capabilities. In this study we hypothesized that millet crop performance and soil water status in the zai technology could be predicted with the CERES-Millet crop model using carefully measured weather and soil data at the experimental site. The specific objective was to evaluate the ability of this model to simulate the performance of millet in the zai system.

\section{Material and Methods}

\section{Experimental Site}

The experiment associated with the present study was conducted in 1999 in farmers' fields at Damari in Niger. Damari is located $45 \mathrm{~km}$ from Niamey, the capital city of Niger, at $13^{\circ} 12^{\prime} \mathrm{N}$ and $2^{\circ} 14^{\prime} \mathrm{E}$. The long-term average annual rainfall is $550 \mathrm{~mm}$, which falls between June and September. The long term monthly average minimum and maximum temperatures vary, respectively, between $16^{\circ} \mathrm{C}$ in January and $28^{\circ} \mathrm{C}$ in April and May and between $32^{\circ} \mathrm{C}$ in January and $42^{\circ} \mathrm{C}$ in April and May (Fig. 6.1). Monthly potential evapotranspiration (PET) is very high; monthly rainfall exceeds PET only in August (Sivakumar et al. 1993). During the experiment

Fig. 6.1 Long term weather data at Damari; 1983-1999
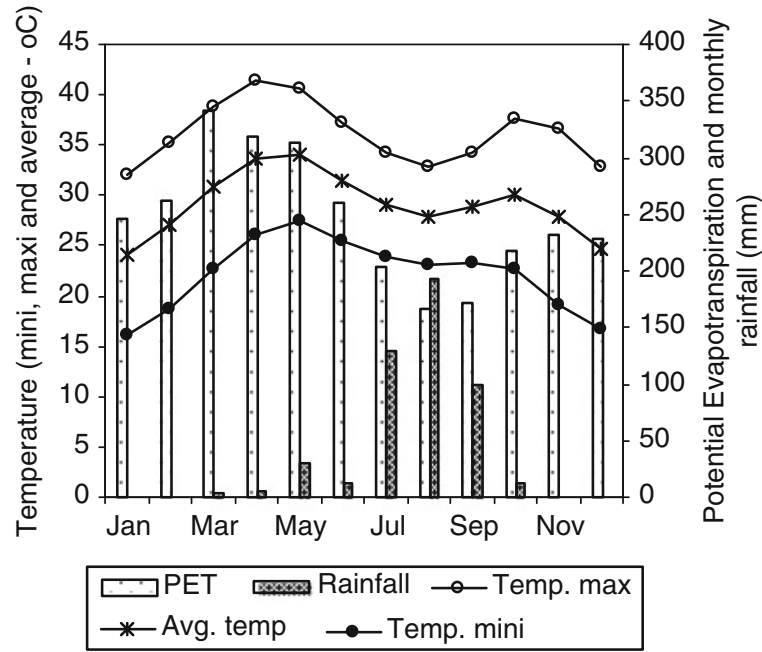


\section{Editor's Proof}

6 Water Use and Yield of Millet Under the Zai System...

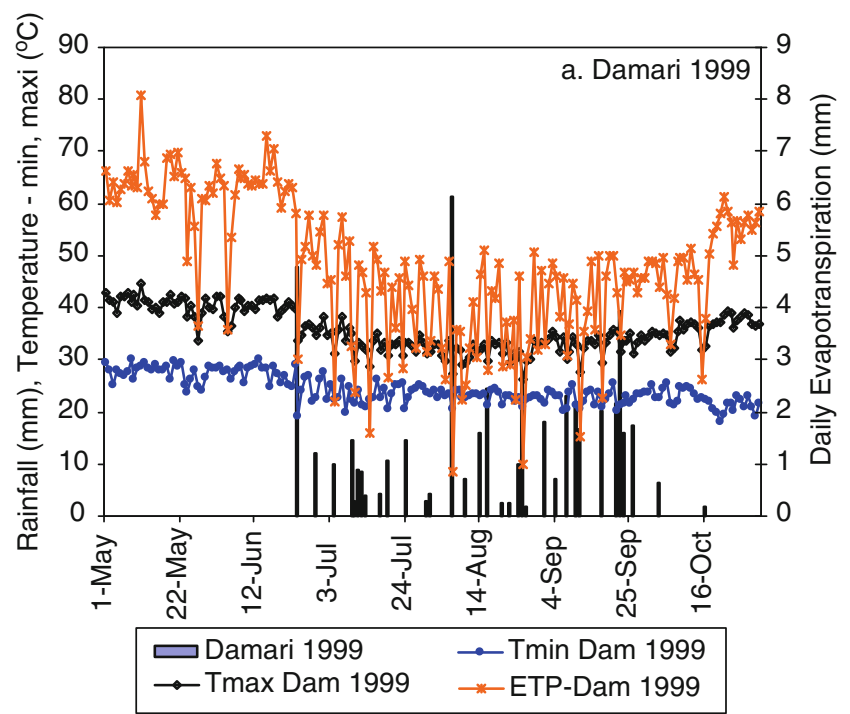

Fig. 6.2 Daily rainfall, minimum and maximum temperature, and potential evapotranspiration at the experiment site, Damari in 1999

in 1999, weather conditions followed this trend; total rainfall for the season was 499 mm (Fig. 6.2).

The soil at Damari is classified as kanhaplic Haplustult (American taxonomySoil Survey Staff 1998). It is acidic ( $\left.\mathrm{pH}-\mathrm{H}_{2} \mathrm{O}=3.6-4.5\right)$, with $84 \%$ sand content, a relatively low effective cation exchange capacity (ECEC) $\left(2.8 \mathrm{cmol} \mathrm{kg}{ }^{-1}\right)$, and a very low soil water holding capacity $(\mathrm{PAWC}=25-600 \mathrm{~mm}$ soil depth approximately). Because of intense rainfall events in the region the soils are prone to surface crusting (Casenave and Valentin 1989) and high runoff rates. The soil organic carbon ranged from $0.04 \%$ to $0.14 \%$ (Fatondji et al. 2006), even lower than the typical levels in Niger (about $0.22 \%$, Bationo et al. 2003). The nutrient levels of soils in the region are very low (Bationo et al. 2003) and severely limit yield compared to the genetic potential of the rainfall environment. Table 6.1 shows measured chemical characteristics of the soil at the experiment site. Available P was far below the level of $2.1 \mathrm{mg} / \mathrm{kg}$ reported by Sinaj et al. (2001) typical to the soils of the Sahel, indicating the advanced degradation status of the soil. Total nitrogen was also very low compared to the average levels for Sub-Saharan Africa reported in Bationo et al. (1996). For other details on the experimental site, refer to Fatondji et al. (2006).

Despite these extreme conditions, farmers are forced to use them for producing crops because of limited land availability. Water harvesting technologies are therefore used to assure better soil water conditions to the crop. Due to the high price of mineral fertilizer, and also the risk of leaching nutrients, farmers use mostly organic 
Table 6.1 Soil profile characteristics of the experiment field at Damari, measured in 1999*

\begin{tabular}{|c|c|c|c|c|c|c|c|c|}
\hline $\begin{array}{l}\text { Land } \\
\text { management }\end{array}$ & $\begin{array}{l}\text { Depth } \\
(\mathrm{cm})\end{array}$ & $\begin{array}{l}\mathrm{pH} \\
\left(\mathrm{H}_{2} \mathrm{O}\right)\end{array}$ & $\begin{array}{l}\text { Total N } \\
\left(\mathrm{mg} \mathrm{kg}^{-1}\right)\end{array}$ & $\begin{array}{l}\text { P-Bray 1 } \\
\left(\mathrm{mg} \mathrm{kg}^{-1}\right)\end{array}$ & $\begin{array}{l}\text { C org } \\
(\%)\end{array}$ & $\begin{array}{l}\text { Sand } \\
(\%)\end{array}$ & $\begin{array}{l}\text { Clay } \\
(\%)\end{array}$ & $\begin{array}{l}\text { Bulk } \\
\text { density } \\
\left(\mathrm{g} \cdot \mathrm{cm}^{-3}\right)\end{array}$ \\
\hline \multirow[t]{4}{*}{$\overline{\text { Flat }}$} & 15 & 3.9 & 0.13 & 1.73 & 0.14 & 84 & 13 & 1.6 \\
\hline & 30 & 3.9 & 0.11 & 1.03 & 0.09 & 83 & 13 & 1.5 \\
\hline & 45 & 3.7 & 0.12 & 0.74 & 0.07 & 84 & 13 & 1.5 \\
\hline & 60 & 3.6 & 0.12 & 0.46 & 0.06 & 85 & 12 & 1.5 \\
\hline \multirow[t]{4}{*}{ Zai $25 \mathrm{~cm}$} & 15 & 4.6 & 0.11 & 1.03 & 0.09 & 84 & 13 & 1.5 \\
\hline & 30 & 3.9 & 0.12 & 0.74 & 0.07 & 83 & 13 & 1.5 \\
\hline & 45 & 3.7 & 0.12 & 0.46 & 0.06 & 84 & 13 & 1.5 \\
\hline & 60 & 3.6 & 0.12 & 0.46 & 0.06 & 85 & 12 & 1.5 \\
\hline \multirow[t]{4}{*}{ Zai $50 \mathrm{~cm}$} & 15 & 4.2 & 0.11 & 1.03 & 0.09 & 84 & 13 & 1.5 \\
\hline & 30 & 3.9 & 0.12 & 0.74 & 0.07 & 83 & 13 & 1.5 \\
\hline & 45 & 3.7 & 0.12 & 0.46 & 0.06 & 84 & 13 & 1.5 \\
\hline & 60 & 3.6 & 0.12 & 0.46 & 0.06 & 85 & 12 & 1.5 \\
\hline
\end{tabular}

*Adapted from Fatondji et al. (2006)

manure in the zai technology. These amendments are often of variable quality with variable decomposition properties.

\section{Field Experiment}

The effect of planting technique (planting on flat vs. planting in zai pits of $25 \mathrm{~cm}$ diameter and pits of $50 \mathrm{~cm}$ diameter $(15-20 \mathrm{~cm}$ deep) and amendment type (control, millet straw, and cattle manure) on millet growth and development were studied. The zai pits were dug in the dry season in the third week of May 1999. When digging the pits, the excavated soil was placed perpendicular to the slope on the lower side of the pit so that water flow would be oriented into the pit. The organic amendments were applied 36 days before sowing at the rate of $300 \mathrm{~g}$ dry weight per pit or pocket (identification of the planting hill on non-zai treated plots) (i.e. $3 \mathrm{t} / \mathrm{ha}$ for both manure and straw). When applied in the flat planting treatments, the amendment was incorporated to $5 \mathrm{~cm}$ depth to protect it from wind that could displace it. When applied in the zai pit, it was not initially covered, but it was covered later due to accumulation of sand and plant material blown and washed into the pit. The field was kept free of weeds throughout the growing season.

The millet straw used as amendment in the study had been collected from experimental fields at Sadoré and cut into small pieces of $10 \mathrm{~cm}$ length, whereas the cattle manure was collected from a barn on the same station. Urine was mixed with the feces, which increased $\mathrm{N}$ and $\mathrm{K}$ content and improved the quality. Table 6.2 presents the chemical composition of these amendments. The $2.53 \% \mathrm{~N}$ concentration of the 
Table 6.2 Nutrient composition (\%) of the organic material used in the experiment ad nutrient applied $\left(\mathrm{kg} \mathrm{ha}^{-1}\right)$

\begin{tabular}{|c|c|c|c|c|c|c|c|}
\hline \multirow{2}{*}{$\begin{array}{l}\text { Organic } \\
\text { amendment }\end{array}$} & \multicolumn{4}{|c|}{ Nutrients content and $\mathrm{C} / \mathrm{N}$ ratio } & \multicolumn{3}{|c|}{$\begin{array}{l}\text { Nutrients applied per } \\
\text { hectare }(\mathrm{kg})\end{array}$} \\
\hline & $\mathrm{N}(\%)$ & $\mathrm{P}(\%)$ & $\mathrm{K}(\%)$ & $\mathrm{C} / \mathrm{N}$ & $\mathrm{N}$ & $\mathrm{P}$ & $\mathrm{K}$ \\
\hline Millet straw & 1.18 & 0.10 & 1.57 & 50 & 32.7 & 2.8 & 43.5 \\
\hline Manure & 2.53 & 0.94 & 1.72 & 21 & 62.9 & 23.3 & 42.8 \\
\hline
\end{tabular}

Adapted from Fatondji et al. (2006)

manure was higher than the $1.2 \% \mathrm{~N}$ for cattle manure typically collected in farmers' corralled fields (Esse et al. 2001).

The experimental design was a Randomized Complete Block Design (RCBD) with two amendments + control (no organic amendment) and three planting techniques (nine treatments) replicated 4 times. Millet variety Sadore local was sown on 28 June at a planting density of 10,000 pockets per ha and harvested at maturity. Plants were thinned to three plants per pocket, approximately 3 weeks after planting.

\section{Measurements}

At maturity, grain and straw dry weight data were collected on a whole plot basis; one border row was left out on each side of the experimental units. The collected data were extrapolated to obtain yield on a per hectare basis.

Volumetric soil moisture contents were measured weekly at $15 \mathrm{~cm}$ intervals down to $210 \mathrm{~cm}$ depth using a neutron probe (Didcot Instrument Company Limited; Wallingford, UK). The probe had been calibrated in-situ for the soils of the experimental site applying the gravimetric method suggested by the manufacturer (Fatondji et al. 2006). The raw neutron probe data were converted to volumetric soil water contents $\left(\mathrm{cm}^{3} \mathrm{~cm}^{-3}\right)$. Two $48 \mathrm{~mm}$ inner diameter aluminum access tube were installed in each experimental plot. One tube was installed between the planting pockets while the second was about $5 \mathrm{~cm}$ from the plants (in the pits in zai-treated plots). Data of the tubes installed close to the plant (on the pocket or in the zai pit) are reported in this chapter. The first measurements were made before the first rainfall on 7 June in 1999 and were continued throughout the growing period until harvest. To study the progress of the profile wetting, several dates were selected to match soil water measurements with other observations which were made in the experiment. These were the date of first measurement before planting, the day of planting as well as days of plant sampling. Only the top $60 \mathrm{~cm}$ soil water data were used in this study because roots did not extend below that depth. Extractable soil water was calculated as the difference between the volume of water at field capacity (or soil water drained upper limit, DUL) in the soil depth to a maximum rooting depth of $60 \mathrm{~cm}$ and the volume of water in the same soil profile at permanent wilting point (or lower limit). Rainwater productivity was calculated as ratio of aboveground biomass or grain yield to the 
amount rain between planting and grain harvest dates and was expressed in $\mathrm{kg}$ per millimeter of rain water. Drainage and runoff are important components of the water balance equation to calculate evapotranspiration. Runoff measurements were not taken during the experiment; therefore evapotranspiration water productivity values were not estimated.

\section{CERES-Millet Model Simulation}

The CERES-Millet model in DSSAT (Tsuji et al. 1994) was used to simulate the effects of the zai and amendment types on aboveground biomass production, grain yield, soil water content, and extractable soil water. Measurements of soil and weather conditions were used to provide the needed inputs to the model. These inputs are (1) the initial chemical and physical status of the soil, which was determined through soil characterization measurements made prior to the installation of the experiment on 12 May 1999. Soil samples were collected up to $200 \mathrm{~cm}$ depth to measure nutrient content and particle size distribution. (2) Nutrient content of the amendments were also measured. (3) Initial soil water conditions were determined using the first neutron probe measurement on 7 June before rain started. The CERES-based organic matter and nitrogen dynamics module (Godwin and Singh 1998) was used. (4) Weather data were collected with an automatic Campbell scientific weather station (daily rainfall, solar radiation, and minimum and maximum air temperature). (5) Lastly, data on the phenology of the crop were collected throughout the cropping season. For comparison with the simulated variables, actual crop yield and final biomass, soil water content, and extractable soil water data were obtained. The root mean square error (RMSE), mean absolute error (MAE) and d-statistic (Willmott 1981) were used to assess the agreement between simulated and observed values.

For the measurement and estimation of all soil parameters vs. depth in the zai treatments, the first measurement starts from the bottom of the pit as the rooting zone of the crop sown in the pit starts from this level. This was taken into account in the initial conditions and the soil characteristic input parameters for the model. Therefore 9 sets of initial conditions and soil analysis were used, which is equal to the number of treatment combinations tested. The fact that the first depth of soil water measurement started from the bottom of the zai pit did not have any influence on initial soil water content. In fact in the flat treatment, the first sampling layer started at the soil surface, whereas in the zai pit it started at the soil surface at the bottom of the pit.

\section{Estimating Model Inputs Not Directly Measured}

Some model parameters are difficult to measure directly and must be estimated from other measurements. In this study, three soil parameters were estimated using weekly soil water content vs. depth measurements in selected treatments: the lower limit of plant available water (LL), the drained up limit (DUL), and the surface 
6 Water Use and Yield of Millet Under the Zai System...

Table 6.3 Initial soil conditions set for the model from measured data in Damari in 1999

\begin{tabular}{lllllll}
\hline & Land \\
management & $\begin{array}{l}\text { Depth } \\
(\mathrm{cm})\end{array}$ & $\begin{array}{l}\text { Initial soil } \\
\text { water content } \\
\left(\mathrm{cm}^{3} \cdot \mathrm{cm}^{-3}\right)\end{array}$ & $\begin{array}{l}\text { Soil water } \\
\text { lower limits } \\
(\mathrm{LL}) \\
\left(\mathrm{cm}^{3} \cdot \mathrm{cm}^{-3}\right)\end{array}$ & $\begin{array}{l}\text { Soil drained } \\
\text { upper limit } \\
(\mathrm{DUL}) \\
\left(\mathrm{cm}^{3} \cdot \mathrm{cm}^{-3}\right)\end{array}$ & $\begin{array}{l}\text { Saturation } \\
\text { point (SAT) } \\
\left(\mathrm{cm}^{3} \cdot \mathrm{cm}^{-3}\right)\end{array}$ & $\begin{array}{l}\text { Nitrate } \\
\text { content } \\
\left(\mathrm{g}[\mathrm{N}] \cdot \mathrm{Mg}^{-1}\right. \\
\text { soil) }\end{array}$ \\
\hline Flat & 15 & 0.022 & 0.024 & 0.065 & 0.361 & 0.007 \\
& 30 & 0.028 & 0.024 & 0.075 & 0.354 & 0.004 \\
& 45 & 0.038 & 0.024 & 0.08 & 0.354 & 0.003 \\
& 60 & 0.042 & 0.024 & 0.08 & 0.358 & 0.002 \\
Zai $25 \mathrm{~cm}$ & 15 & 0.026 & 0.024 & 0.08 & 0.361 & 0.004 \\
& 30 & 0.037 & 0.024 & 0.08 & 0.354 & 0.003 \\
& 45 & 0.044 & 0.024 & 0.09 & 0.354 & 0.002 \\
& 60 & 0.046 & 0.024 & 0.09 & 0.358 & 0.002 \\
Zai $50 \mathrm{~cm}$ & 15 & 0.027 & 0.024 & 0.08 & 0.361 & 0.004 \\
& 30 & 0.038 & 0.024 & 0.08 & 0.354 & 0.003 \\
& 45 & 0.041 & 0.024 & 0.09 & 0.354 & 0.002 \\
& 60 & 0.046 & 0.024 & 0.09 & 0.358 & 0.002 \\
\hline
\end{tabular}

water runoff curve number (ROCN). Although there are pedotransfer functions for estimating LL and DUL, from measured soil texture, these functions are not reliable for specific field sites (Gijsman et al. 2003). Genetic coefficients and an inherent soil productivity factor were estimated using maturity date, biomass and grain yield measurements in the manure treatments. Finally maximum root depth was estimated using soil $\mathrm{pH}$ and water measurements. Although these estimates were obtained by indirect methods, they are based on measurements that provided consistent predictions taking into account the many interacting factors.

To estimate the soil water LL, we took the average of the measured soil water contents of the first two soil layers (15 and $30 \mathrm{~cm}$ depths) taken on 7 June before the first rain of the season. Due to the long dry season from October, these first two layers were dry. The average volumetric water content of the two layers was $0.024 \mathrm{~cm}^{3} \cdot \mathrm{cm}^{-3}$. We did not include the lower depths as higher values indicated that those layers probably did not reach the lower limit. To estimate DUL, the neutron probe readings were also used. Flat-planted control and $50 \mathrm{~cm}$ zai control treatments were used to estimate DUL for each layer for flat and zai treatments, respectively. The DUL was set to approximate the soil water values measured after rainfall had wet the soil, but before plants started rapidly extracting water. The results are reported in Table 6.3

Due to soil crusting, runoff was high in flat-planted treatments. Therefore a high coefficient (ROCN) was set for this treatment by comparing the time series of measured and simulated soil water contents in the control and manure flat-planted treatments. Iteratively, ROCN values were changed until simulated soil water vs. depth and time of season in these two treatments were in good agreement with observed soil water contents. Following this procedure, a runoff coefficient of 98.4 was obtained for the flat treatment. To estimate the runoff coefficient for the two zai pit 
Table 6.4 Genetic coefficients for the millet variety used in the study

\begin{tabular}{|c|c|c|}
\hline$\underline{\text { Parameter }}$ & $\begin{array}{l}\text { Initial values } \\
\text { (variety CIVT) }\end{array}$ & Values \\
\hline $\begin{array}{l}\text { Thermal time from seedling emergence to the end of the juvenile } \\
\text { Phase (P1) }\end{array}$ & 180 & 170 \\
\hline $\begin{array}{l}\text { Critical photoperiod or the longest day length (in hours) at which } \\
\text { development occurs at a maximum rate (P20) }\end{array}$ & 12 & 12 \\
\hline $\begin{array}{l}\text { Extent to which phasic development leading to panicle initiation } \\
\text { (expressed in degree days) is delayed for each hour increase } \\
\text { in photoperiod above (P2R) }\end{array}$ & 150 & 150 \\
\hline $\begin{array}{l}\text { Thermal time (degree days above a base temperature of } 10^{\circ} \mathrm{C} \text { ) } \\
\text { from beginning of grain filling ( } 3-4 \text { days after flowering) } \\
\text { to physiological maturity(P2OP5) }\end{array}$ & 500 & 450 \\
\hline Scalar for relative leaf size $(\mathrm{G} 1)$ & 2 & 1 \\
\hline Scalar for partitioning of assimilates to the panicle (G5) & 0.50 & 0.77 \\
\hline $\begin{array}{l}\text { Phylochron interval; the interval in thermal time (degree days) } \\
\text { between successive leaf tip appearances. (PHINT) }\end{array}$ & 43 & 43 \\
\hline
\end{tabular}

sizes, we calculated the proportion of area occupied by a zai relative to the total area per pocket $\left(1 \mathrm{~m}^{2}\right)$. Although water falling between the pits has a chance to be captured in the pits, for simplicity we assumed that any drop falling between the pits would runoff at a rate determined by the ROCN of the flat treatment and all rain falling on the area of the pit would be retained. Based on this assumption we calculated a weighted average ROCN using the runoff coefficient of the flat planting and relative area of the zai hole to the area not in the hole. Therefore we obtained a ROCN of 93.5 for the zai of $25 \mathrm{~cm}$ diameter and 79.1 for the zai of $50 \mathrm{~cm}$ diameter. One ROCN was used for each planting technique regardless of amendment.

\section{Genetic Coefficients}

Genetic coefficients were estimated using measured biomass and grain yield and physiological maturity date for the zai manure treatments. Ideally, genetic coefficients should be estimated using data collected in experiments without water and nutrient stresses, but this is not possible in many cases such as in this experiment. Following Boote et al. (2003) and Mavromatis et al. (2001), coefficients for a variety in the DSSAT millet cultivar file was initially used, and phenology coefficients (P1, P2R, and P2OP5) were adjusted so that the simulated maturity date closely approximated the mean observed date for the manure treatments (good, least nutrient stress treatment) (Table 6.4.). Afterward, coefficients that determine biomass production and its partitioning into grain yield were considered. However, this was done simultaneously with adjustments to the soil fertility factor (SLPF), which must be used to account for limited nutrients in the soil that are not included in the model. Other researchers (e.g., Singh et al. 1994; Naab et al. 2004) found that SLPF values ranging between 0.63 and 1.00 were necessary for some soils in India and Ghana. 
In this case, it was noted that soil P levels were very low, which justified our modification of this factor. Thus, G5, the parameter that partitions assimilates into grain, and SLPF were modified together using both grain and biomass yield as criteria.

Maximum rooting depth is determined by a root growth factor (SRGF) in each soil layer. Layers down to the maximum root depth have values computed from the DSSAT software, and values below that were set to 0.0. In this study, it was assumed that due to $\mathrm{Al}$ toxicity and low $\mathrm{pH}$ below $30 \mathrm{~cm}$ depth, roots would not grow below $30 \mathrm{~cm}$. This was consistent with the neutron probe data that showed no soil water extraction below that depth. Therefore SRGF was set to zero for all layers below that depth.

\section{Results and Discussion}

\section{Experiments}

Soil water content. Figure 6.3 shows graphs of soil water content vs. depth for different measurement dates for the $25 \mathrm{~cm}$ zai and flat planted treatments. The same trend was observed for both pit sizes, but soil water contents were higher for the plots with the $50 \mathrm{~cm}$ diameter zai. The wetting front was already below $200 \mathrm{~cm}$ on the day of planting in the zai treated plots (Fig. 6.3a, c, e), whereas in the non-zai treated plots, it was shallower on the same date (Fig. 6.3b, d, f). The results indicate that even though the structure of the soil is sandy, breaking the surface crust and digging the pits was highly favorable for water infiltration compared to the flat treatment. Volumetric soil water content (VWC) was still higher at deeper layers in the zai vs. the flat treatments even towards the end of the season. In the control-zai plots for instance, at $200 \mathrm{~cm}$ depth, VWC was about $0.08 \mathrm{~cm}^{3} / \mathrm{cm}^{3}$ compared to $0.051 \mathrm{~cm}^{3} /$ $\mathrm{cm}^{3}$ for the flat-control treatment.

In general, the soil water profile was shallower in the manure treated plots than the other treatments regardless of the type of planting technique. Towards the end of the cropping season, in the zai as well as on flat treatment with cattle manure, soil water content decreased significantly compared to plots treated with millet straw, indicating high water consumption of the crop due to increased biomass production. Particularly in flat treatment amended with cattle manure, the wetting front remained at $60 \mathrm{~cm}$ during the whole growing period, which is an indication that the presence of crust hampered water infiltration. But in addition crop water uptake may have increased considerably due increased biomass production

Extractable soil water (ESW) was calculated based on a maximum depth of $60 \mathrm{~cm}$ for comparison with the output of the model. In the flat-planted plots, extractable soil water was lower than in the zai-treated plots regardless of the amendment type (Fig. 6.4). This was more pronounced in the manure treated plot probably due to higher plant consumption as reported in Fatondji et al. (2006). Biomass and grain yield on these plots were high compared to the control. The same thing may have happened in the $25 \mathrm{~cm}$ diameter zai amended with manure where extractable soil 


\section{Editor's Proof}

a

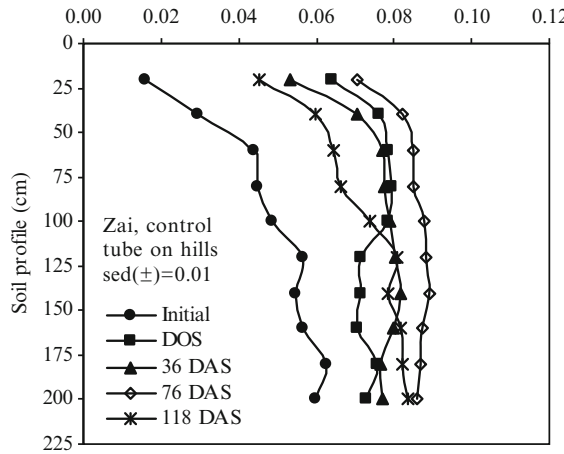

c

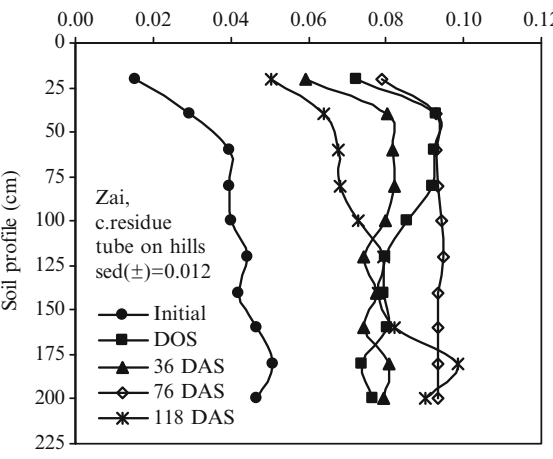

e

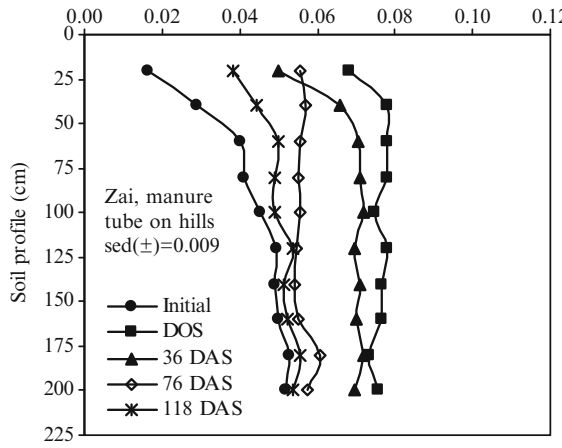

b Volumetric water content $\left(\mathrm{cm}^{3} \cdot \mathrm{cm}^{-3}\right)$

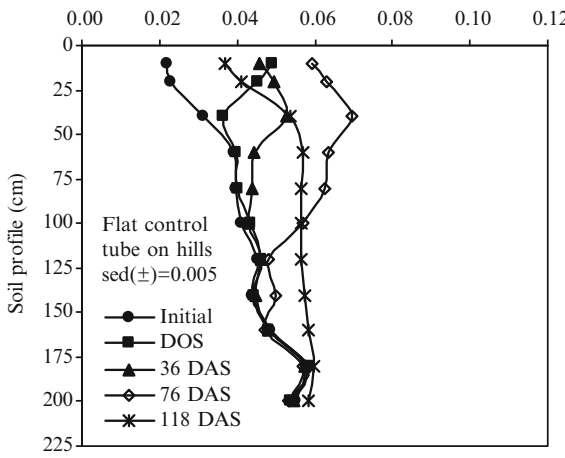

d

Volumetric water content $\left(\mathrm{cm}^{3} \cdot \mathrm{cm}^{-3}\right)$

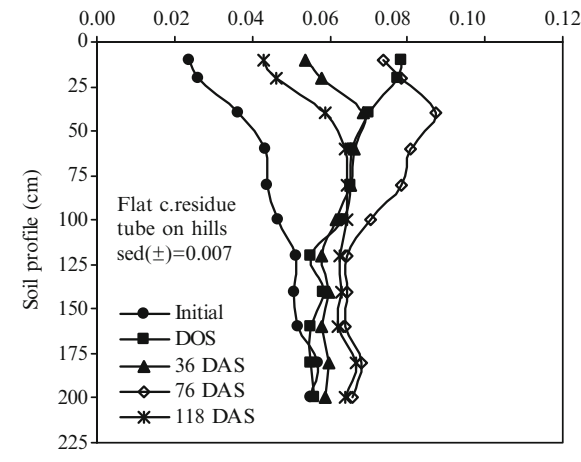

f

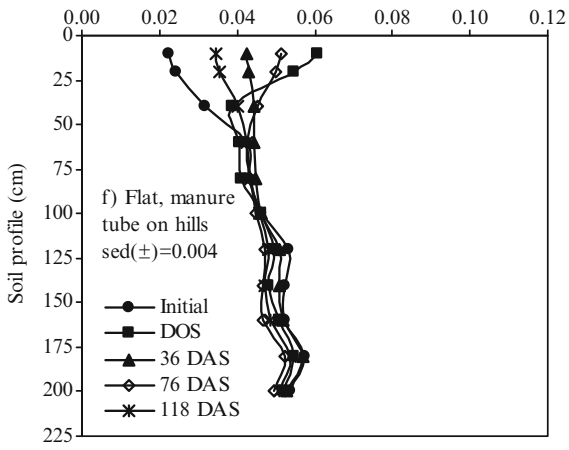

Fig. 6.3 Effect of planting technique and amendment type of soil water content. Damari; Sed standard error of difference between means 


\section{Editor's Proof}

6 Water Use and Yield of Millet Under the Zai System...

a

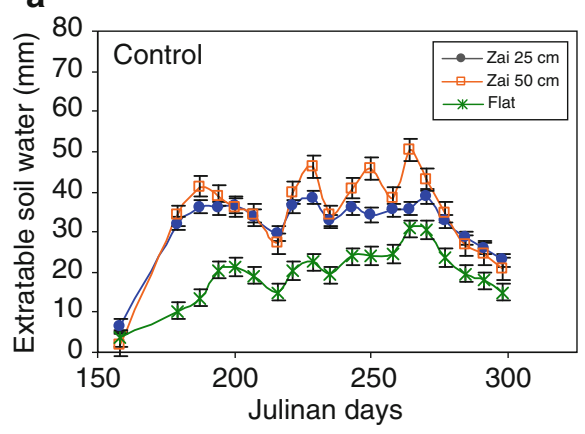

b

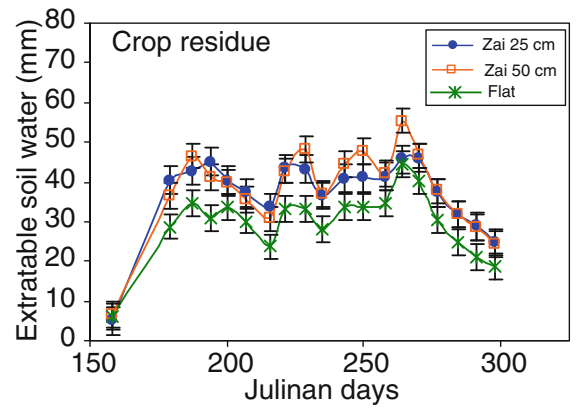

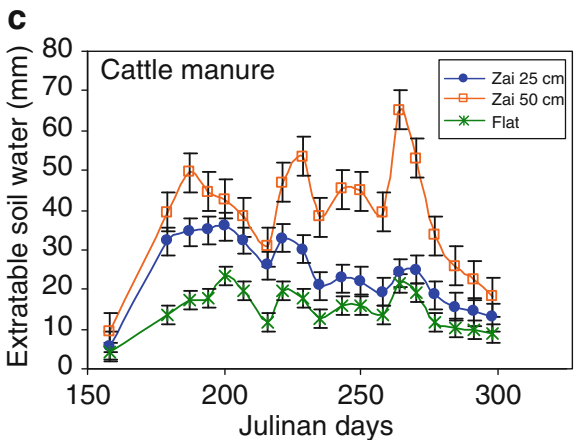

Fig. 6.4 Effect of planting technique and amendment type on extractable soil water

water dropped substantially from day 240 until the end of the cropping season, which was not the case of the zai of $50 \mathrm{~cm}$ diameter. This is an indication that more water was collected in pits of $50 \mathrm{~cm}$ diameter.

Yield components. In the control non-amended plots, the zai treatment increased above ground biomass yield by a factor 3 for both pit sizes, while grain yield increased by a factor 19 for pit size $25 \mathrm{~cm}$ diameter and 9 for pit size $50 \mathrm{~cm}$ (Table 6.5). Nevertheless the yields were extremely low compared to the average millet grain yield in Niger, which is $300 \mathrm{~kg} \mathrm{ha}^{-1}$ (Bationo et al. 1989). No farmer would crop a field that would produce $1 \mathrm{~kg} \mathrm{ha}^{-1}$ of grain. This is an indication that crop production would not be possible without external nutrient inputs in the soil where the experiment was conducted. It also shows that water is not the major constraint. Only minor yield increases were observed in the zai compared to flat planting when crop residue was applied.

The zai treatment significantly increased the above ground biomass $\left(5,133 \mathrm{~kg} \mathrm{ha}^{-1}\right.$ and $5,711 \mathrm{~kg} \mathrm{ha}^{-1}$ for the $25 \mathrm{~cm}$ and $50 \mathrm{~cm}$ zai, respectively) compared to $2,967 \mathrm{~kg} \mathrm{ha}^{-1}$ for flat planting, when cattle manure was applied. Grain yield also increased $\left(1,156 \mathrm{~kg} \mathrm{ha}^{-1}\right.$ and $1,100 \mathrm{~kg} \mathrm{ha}^{-1}$ for $25 \mathrm{~cm}$ zai and $50 \mathrm{~cm}$ zai, respectively) compared to $705 \mathrm{~kg} \mathrm{ha}^{-1}$ for flat planting (Table 6.5). This shows that by breaking the crust with the zai digging, better conditions were created for crop growth. This may 
Table 6.5 Millet above ground biomass and grain yield as affected by planting technique under various fertility management conditions, Damari 1999

\begin{tabular}{|c|c|c|}
\hline \multirow[b]{2}{*}{ Treatments } & \multicolumn{2}{|c|}{ Yield data $\left(\mathrm{kg} \mathrm{ha}^{-1}\right)$} \\
\hline & $\begin{array}{l}\text { Above ground } \\
\text { biomass }\end{array}$ & Grain \\
\hline \multicolumn{3}{|l|}{ Control } \\
\hline Flat planting & 96 & 1 \\
\hline Zai $25 \mathrm{~cm}$ & 303 & 17 \\
\hline Zai $50 \mathrm{~cm}$ & 280 & 8 \\
\hline $\operatorname{Sed}( \pm)$ & 90.4 & 4.9 \\
\hline F.prob & ns & 0.045 \\
\hline \multicolumn{3}{|l|}{ Crop residue } \\
\hline Flat planting & 795 & 127 \\
\hline Zai $25 \mathrm{~cm}$ & 1,059 & 168 \\
\hline Zai $50 \mathrm{~cm}$ & 924 & 157 \\
\hline Sed $( \pm)$ & 232.5 & 48.9 \\
\hline F.prob & ns & ns \\
\hline \multicolumn{3}{|l|}{ Manure } \\
\hline Flat planting & 2,967 & 705 \\
\hline Zai $25 \mathrm{~cm}$ & 5,133 & 1,157 \\
\hline Zai $50 \mathrm{~cm}$ & 5,711 & 1,100 \\
\hline $\operatorname{Sed}( \pm)^{\mathrm{a}}$ & 872.8 & 276.1 \\
\hline F.prob & 0.044 & $\mathrm{~ns}$ \\
\hline
\end{tabular}

Adapted from Farondji et al. (2006)

${ }^{\text {a }} \mathrm{Sed}$ Standard error of difference between means

have also helped the crops to escape from the effect of dry spells. In the Sahel, and particularly during this experiment, dry spells resulting in 2 weeks without rain were frequent (Fatondji et al. 2006). The observed differences were statistically significant only for millet aboveground biomass yield when cattle manure was applied and for grain yield of the control non-amended plots. No statistically significant differences were observed between the zai pit sizes in terms of above ground biomass and grain yield. This could be due to high variability in the data because of the harsh conditions of the experiment, particularly in the control and the crop residue amended plots. The residual mean square error was even higher than the treatment mean for crop residue amended plots. Nevertheless, we speculate that soil nutrient content was so low, that water availability alone without application of nutrients made only small differences in crop productivity among the soil management techniques.

In flat-planted plots, $2,900 \mathrm{~kg} \mathrm{ha}^{-1}$ of aboveground biomass yield was obtained with manure application compared to $1,200 \mathrm{~kg} \mathrm{ha}^{-1}$ for crop residue and $96 \mathrm{~kg} \mathrm{ha}^{-1}$ for the control non-amended plot. Relatively high grain yield production was also obtained with manure application in flat-planted plots $\left(705 \mathrm{~kg} \mathrm{ha}^{-1}\right)$ compared to $127 \mathrm{~kg}$ and $1 \mathrm{~kg} \mathrm{ha}^{-1}$ for crop residues and control non-amended plots, respectively (Table 6.6). All observed differences were statistically significant. In both zai pit sizes, manure application significantly increased aboveground biomass and grain yield compared to the crop residue and the control treatments. In the $25 \mathrm{~cm}$ diameter 
Table 6.6 Millet above ground biomass and grain yield as affected by amendment type under various soil management conditions, Damari 1999

\begin{tabular}{|c|c|c|}
\hline Treatments & $\begin{array}{l}\text { Above ground } \\
\text { biomass }\left(\mathrm{kg} \mathrm{ha}^{-1}\right)\end{array}$ & $\begin{array}{l}\text { Grain } \\
\text { yield } \\
\left(\mathrm{kg} \mathrm{ha}^{-1}\right)\end{array}$ \\
\hline \multicolumn{3}{|l|}{ Flat planting } \\
\hline Control & 96 & 1 \\
\hline Crop residue & 1,159 & 127 \\
\hline Manure & 2,967 & 705 \\
\hline $\operatorname{Sed}( \pm)$ & 597.3 & 215.4 \\
\hline Fprob & 0.008 & 0.036 \\
\hline \multicolumn{3}{|l|}{ Zai $25 \mathrm{~cm}$} \\
\hline Control & 303 & 17 \\
\hline Crop residue & 1,195 & 1,68 \\
\hline Manure & 5,133 & 1,157 \\
\hline $\operatorname{Sed}( \pm)$ & 666.2 & 112.6 \\
\hline Fprob & $<0.001$ & $<0.001$ \\
\hline \multicolumn{3}{|l|}{ Zai $50 \mathrm{~cm}$} \\
\hline Control & 280 & 8 \\
\hline Crop residue & 924 & 157 \\
\hline Manure & 5,711 & 1,100 \\
\hline $\operatorname{Sed}( \pm)$ & 406.9 & 79.8 \\
\hline Fprob & $<0.001$ & $<0.001$ \\
\hline
\end{tabular}

Sed Standard error of difference between means Adapted from Fatondji et al. (2006)

zai treatment amended with manure, aboveground yield increased by a factor 17 compared to the control and a factor of 4 compared to crop residue treatments. The same trend was observed in grain yield but more pronounced as manure application in the $50 \mathrm{~cm}$ zai treatment increased yield by factors of 138 and 7 for the control and crop residue treatments, respectively. Grain yield in crop residue-amended plots was higher than the control by a factor 4 and 7 in the 50 and $25 \mathrm{~cm}$ zai treatments, respectively. All the differences were highly significant statistically (Table 6.6). These results show that for better results with the zai technology, there is a need of additional nutrient input of good quality. Nevertheless, due to the excess water that would collect in the zai, it may be preferable to use organic amendment for nutrient input instead of inorganic fertilizers that tend to leach with water drainage.

Table 6.7 shows the effects of organic amendment type on observed rain water productivity and simulated results for the same parameter for comparison. Manure application in the zai resulted in above ground yield of $12 \mathrm{~kg} \cdot \mathrm{mm}^{-1}$ of rain on average versus $0.6 \mathrm{~kg} \mathrm{~mm}^{-1}$ of rain for the control treatment. Grain yield per $\mathrm{mm}$ of rain water also increased by a factor 64 and 128 for zai $25 \mathrm{~cm}$ and zai $50 \mathrm{~cm}$, respectively, compared to the control non-amended plots. On flat-planted plots, manure application increased rain water productivity by a factor 31 . All the observed differences were statistically significant. When compared to flat planted 
Table 6.7 Rainfall water productivity as affected by amendment type under various soil management practices; Damari 1999

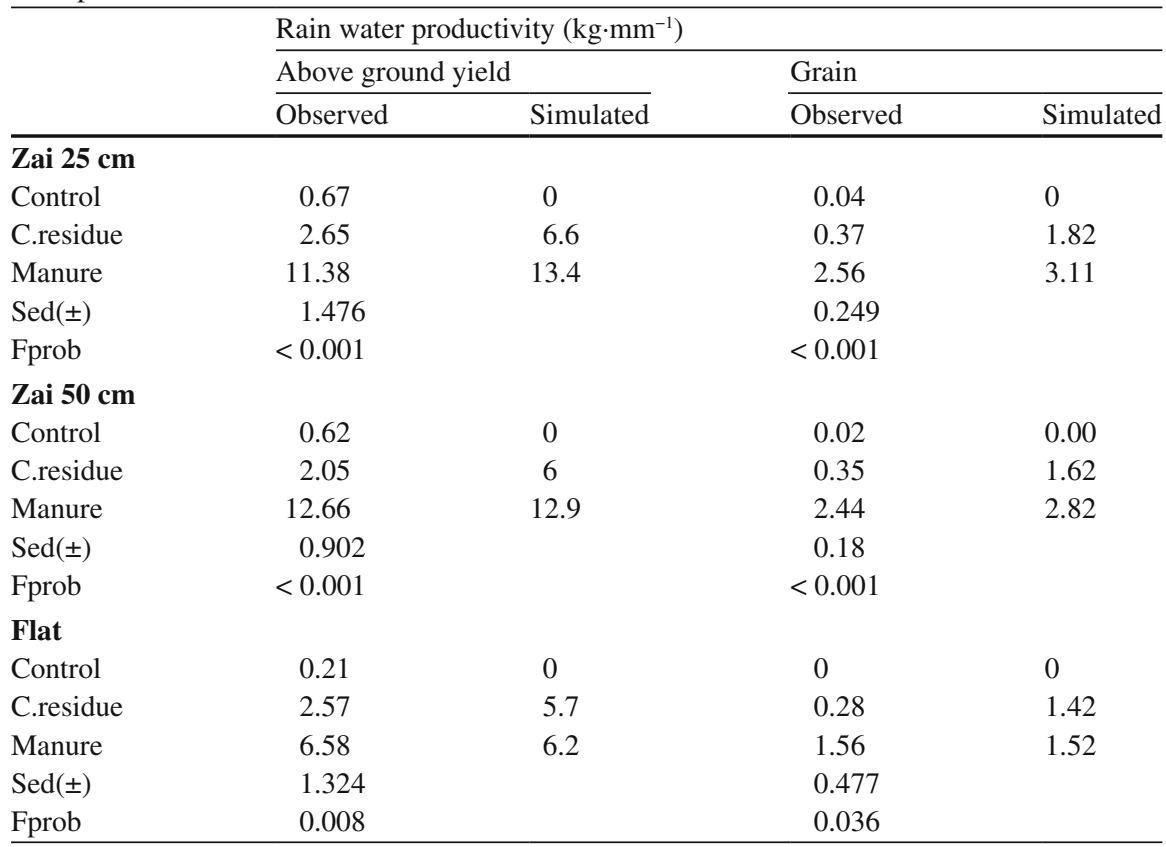

C.residue Crop residue, Sed Standard error of difference between means

plots, manure application in the zai improved aboveground biomass and grain yield per mm of rain by a factor 2 . These results indicate that the crop made better use of rain water in the zai when manure was applied. Similar results were reported by Fatondji et al. (2006) on another experimental site where the same technologies were tested.

\section{Simulated Results}

Soil water content. Figure 6.5 shows the simulated soil water contents for the control flat planted treatment for soil layers 5-15 and 15-30 cm compared to the observed data. In general there is a good prediction of the movement of the wetting front in the 5-15 cm layer during all the sampling period except for the 4th and the 14th sampling dates, which correspond to period of successive rainfall events (the first was taken 1 day after 3 days of rain (total of $26 \mathrm{~mm}$ ) and the second was taken 1 day after a rain event of $21 \mathrm{~mm}$ ) which were under-predicted. The seventh and tenth samplings, which were taken after 11 and 7 days of dry spells, respectively, were over-predicted. In general the model performed poorly in predicting soil water 


\section{Editor's Proof}

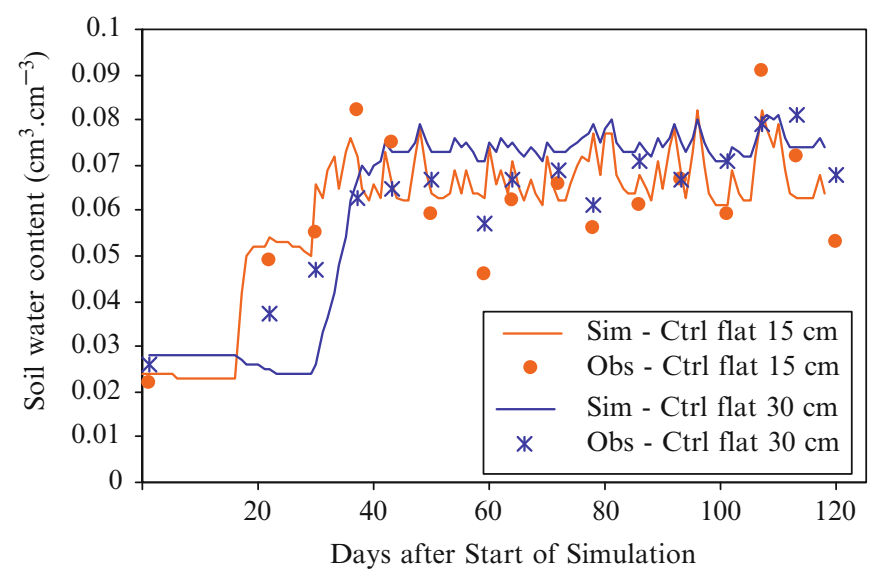

Fig. 6.5 Soil water content in the flat control treatment, soil layers $5-15$ and $15-30 \mathrm{~cm}$. Simulated (Sim) and observed $(\mathrm{Obs})$ data

content in the 15-30 cm layer. It grossly under-predicted the second sampling, which was 4 days after $48 \mathrm{~mm}$ of rain and the third sampling, which was 2 days after $10 \mathrm{~mm}$ of rain. Subsequently, the model predicted high water content all along the sampling period except for samplings 11, 13 and 14, which were taken 4 days after cumulative rains of 39, 38 and $20 \mathrm{~mm}$ and which were all well predicted. In both soil layers, the dry spells were over-predicted. Our observation is that there is no consistent trend on which we could base our argument in relation to the prediction of soil water content depending upon the number of days before or after rainfall event. Nevertheless we have to admit that the time resolution of this model would not allow this level of detail.

Overall, the ability of the model to simulate over most of the season was good as supported by the low residual mean square error $(\mathrm{RMSE}=0.01)$, high d-statistic of 0.9 and r-square of 0.7. Figure 6.6 shows the simulation results of the control zai for the same soil layers. The general trend was well simulated, although the model simulated more peaks that were not observed from the field measurements. We also point out that the model can be off by one day, since it is not indicated exactly when during a day the rainfall occurred, and at what time measurements were taken. Figure 6.7 shows the simulated soil water contents in the manure amended zai $50 \mathrm{~cm}$ plot. In general the measured trend was captured; nevertheless the $11^{\text {th }}$ sampling that was after 4 days of cumulative rainfall of $39 \mathrm{~mm}$ was not simulated accurately by the model. Actually, there was no consistent relationship between the trends in observed rainfall events and the time of sampling as per our observations. Nevertheless, further studies may be needed to address these details which may help us understand why the model over-predicted water content in some cases while in other less water content was predicted compared to the observed values. 


\section{Editor's Proof}

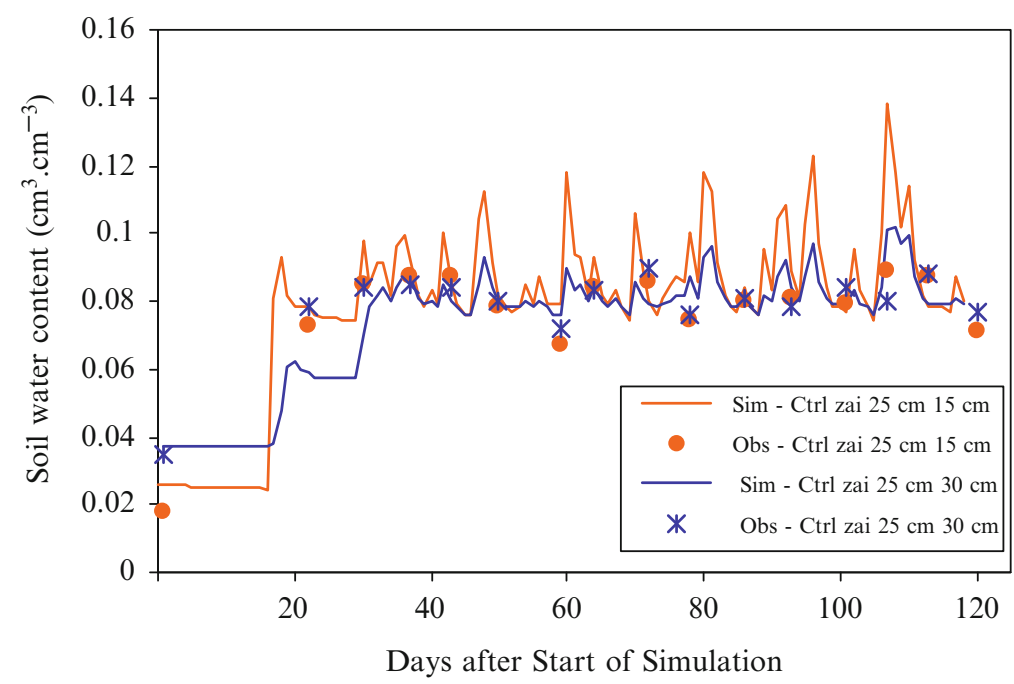

Fig. 6.6 Soil water content in the zai control treatment, soil layers 5-15 and 15-30 cm. Simulated (Sim) and observed $(\mathrm{Obs})$ data

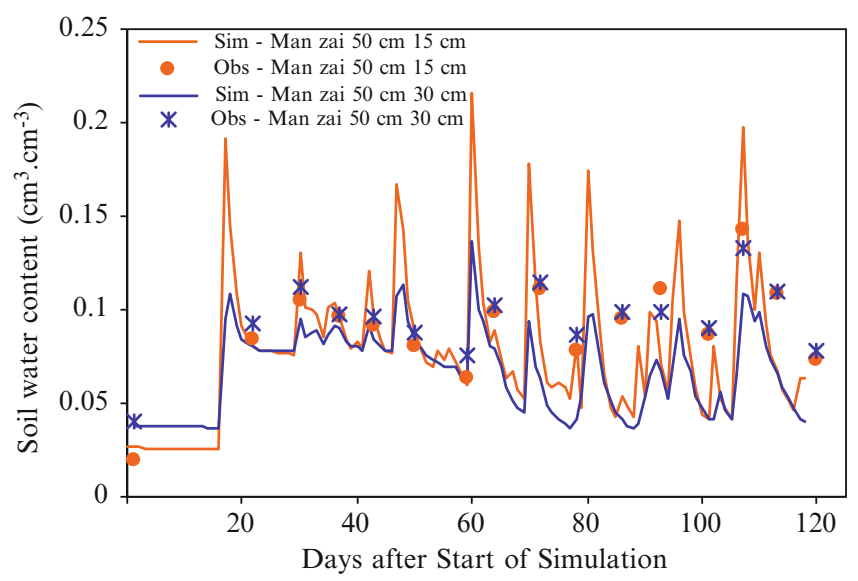

Fig. 6.7 Soil water content in the zai $50 \mathrm{~cm}$ manure treatment, soil layers 5-15 and 15-30 cm. Simulated $(\mathrm{Sim})$ and observed $(\mathrm{Obs})$ data

Figure 6.8 shows the extractable soil water in the top $60 \mathrm{~cm}$ of soil. The observed trend was captured by the model in the control flat and manure zai $50 \mathrm{~cm}$ with high d-statistics (0.913 and 0.821) except for the samplings 11 and 12, which were overestimated as observed already with the graph of soil water content in the $50 \mathrm{~cm}$ zai treatment amended with manure. The manure flat treatment had a lower d-statistic (0.618) and very low r-square of 0.37 ; but a fairly low RMSE (5.953). One of the major inputs of the zai technology is the breakage of the soil crust while digging the 


\section{Editor's Proof}

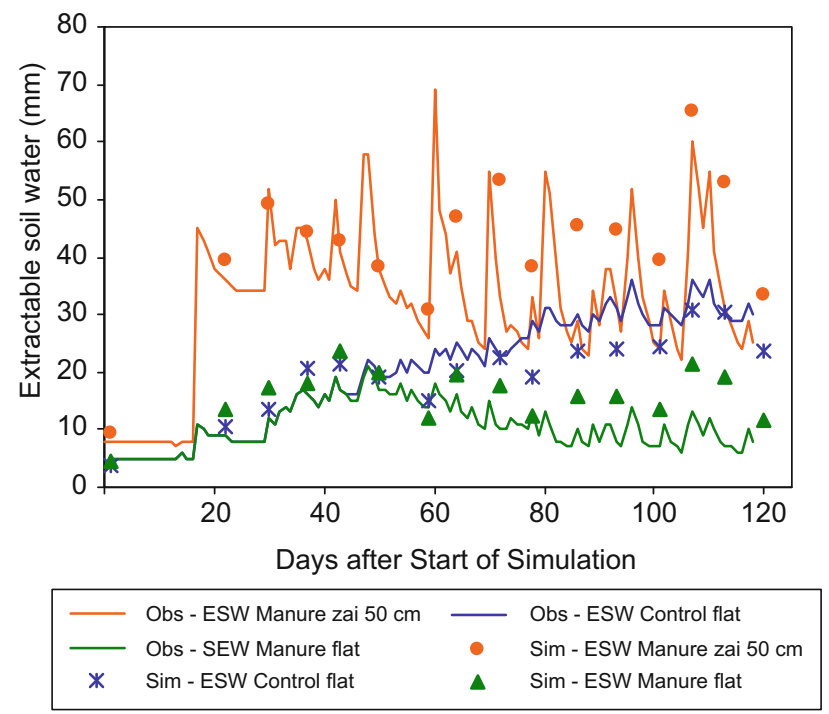

Fig. 6.8 Extractable soil water $(E S W)$ in the control and manure flat + manure zai $50 \mathrm{~cm}$ treatments; Simulated ( $\mathrm{Sim})$ and observed $(\mathrm{Obs})$ data

zai holes. Depending upon the size of the pit, the amount of water collected may differ. The results presented here were obtained by using a different runoff curve number for each land management treatment (flat, zai $25 \mathrm{~cm}$ and zai $50 \mathrm{~cm}$ ). The general trend was that almost no water extraction occurred below the top $45 \mathrm{~cm}$ of soil, which according to Fatondji (2002) was the depth above which $98 \%$ of the plant roots (dry weight basis) were concentrated. High Al content (29\%) of the experiment soil (Fatondji et al. 2006) hampered root growth beyond the zone of application of the organic amendment, which could explain why water extraction did not occur at those depths. Nevertheless some water would move upward from the 30-60 cm layer as the upper layer dries out, and thus plants will extract some of the water from the 30-60 depth due to diffusion even if roots are not in that layer.

\section{Yield Components}

Table 6.4 shows the genetic coefficients estimated for the Sadore local variety used in this experiment. The estimated value of SLPF was 0.68. These genetic coefficients and the SLPF were then used for all other treatments in the experiment. Table 6.8 shows statistics comparing simulated vs. observed biomass and grain yield for flat-planted and zai treatments with manure and with no amendments (six treatments). Although the manure treatments were used to estimate these parameters, these results demonstrate a good ability of the millet model to simulate differences among these six treatments, with high r-square and d-statistics and low root 
Table 6.8 Simulated vs. observed aboveground biomass and grain yield - statistical comparisons

\begin{tabular}{|c|c|c|c|c|c|c|c|}
\hline \multirow[b]{2}{*}{ Variable name } & \multicolumn{3}{|c|}{$\operatorname{Mean}\left(\mathrm{kg} \cdot \mathrm{ha}^{-1}\right)$} & \multicolumn{2}{|c|}{ Mean $\left(\mathrm{kg} \cdot \mathrm{ha}^{-1}\right)$} & \multicolumn{2}{|l|}{ RMSE } \\
\hline & Observed & Simulated & $\overline{\text { r-Square }}$ & Difference & $\overline{\text { Abs.Diff. }}$ & $\overline{\left(\mathrm{kg} \cdot \mathrm{ha}^{-1}\right)}$ & d.stat \\
\hline \multicolumn{8}{|c|}{ Control, crop residue and manure } \\
\hline Total biomass & 1,974 & 2,441 & 0.847 & 467 & 711 & 943.2 & 0.948 \\
\hline Grain yield & 382 & 591 & 0.728 & 209 & 225 & 327.755 & 0.885 \\
\hline \multicolumn{8}{|c|}{ Control and manure only } \\
\hline Total biomass & 2,415 & 2,339 & 0.988 & -76 & 290 & 340.026 & 0.995 \\
\hline Grain yield & 498 & 536 & 0.991 & 39 & 63 & 93.045 & 0.993 \\
\hline
\end{tabular}

$d$-stat d-statistic Willmott (1981), Abs.Diff. Absolute difference

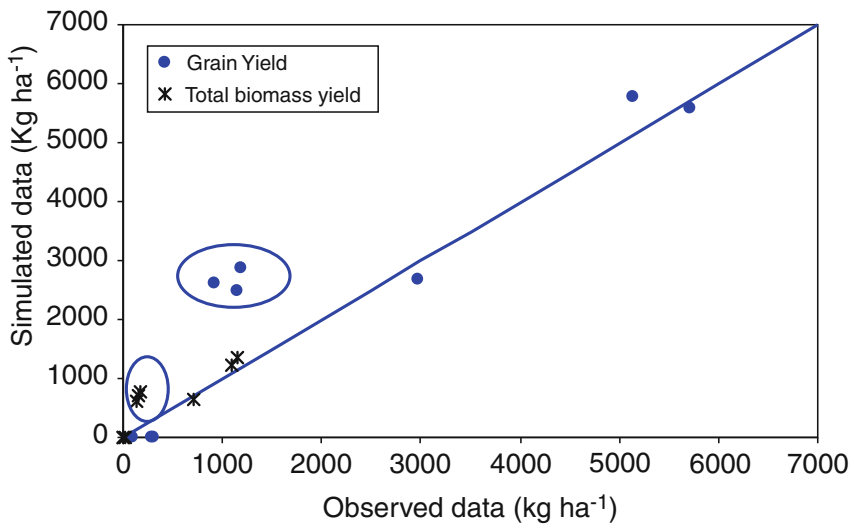

Fig. 6.9 Observed versus simulated top dry matter and grain yield. Circled points are for the crop residue treatments

mean square errors between simulated and observed data. Due to the marginal conditions of the experiment in terms of soil physical and chemical characteristics, the crops were so stressed in some treatments that they could hardly grow and simulated growth was very low relative to the crop's genetic potential (control nonamended plots). Although these conditions are extreme to be simulated by conventional models, these results show that by setting the parameters for conditions in this experiment the model was able to simulate the observed responses to these six treatments.

However, the simulation results for the crop residue treatments substantially over-predicted observed yields (Fig. 6.9 - circled symbols). The model may have under-predicted immobilization of $\mathrm{N}$ following addition of the high $\mathrm{C}: \mathrm{N}$ residues in this treatment.). One other possibility is that the low response observed in the experiment relative to simulated yield may have been due to the very low phosphorus content in the crop residue. Phosphorus concentration in the crop residue was $0.10 \%$, whereas it was $0.94 \%$ for cattle manure. The version of the millet model in DSSAT v4.5 used in this study did not account for phosphorus limitations to growth, 
although this option is available for other crops (Dzotsi 2007). This means that simulated yields for this experiment were based only on water and nitrogen availability in addition to weather and genetic coefficients. When soils have very low phosphorus levels, and very little or no phosphorus is applied as an amendment or fertilizer, the model may over-predict biomass growth and grain yield, which is what happened in the crop residue treatments. It is also possible that the nutrient content of the crop residue was highly variable and inputs for this amendment were not accurate. In manure treatments, as manure decomposed it released about 9 times more phosphorus than the decomposing crop residue, which apparently favored crop growth and yield. This trend is not captured by the model as the phosphorus module is not yet available in DSSAT for millet.

The model performed very well in terms of rain water productivity, particularly for manure and control plots; whereas the effect of crop residue was not well captured in the model outputs (Table 6.7). This implies that water productivity estimated by the model can be used to estimate rain water productivity for comparing the zai with manure amendment vs. control flat planted management systems in other years or locations if the required soil, weather, amendment, and planting technique model inputs are known.

\section{Discussion and Conclusions}

This study addressed the challenge of simulating low productivity of millet due to combination of crusting soils (with adverse effects on soil water balance), extremely low PAWC soils, $\mathrm{N}+\mathrm{P}$ constraints on crop growth and low and erratic rainfall. We explored the possibility of simulating millet production in one of the extreme conditions that farmers have to deal with using an experiment in which detailed data were collected on soil physical and chemical properties, organic amendment properties, weather, yield components, and weekly soil water content vs. depth measurements for nine treatment combinations of planting techniques and organic amendments. These carefully-collected data provided a good test of how well the millet model would predict the range of responses that were observed. But even with the extensive data set, we found that several input parameters needed by the model had to be estimated using indirect methods. Although this need may exist in other conditions, the model was highly sensitive to these uncertain inputs for the conditions at this site. The most sensitive inputs that had to be estimated indirectly were the genetic coefficients for the variety used in the experiment, the runoff curve number for different zai vs. flat planted treatments, and the soil fertility factor. Nevertheless, simulated yield results were very good for the manure treatments on flat planted and zai treatments, predicting aboveground biomass values that ranged between about 3,000 and $5,700 \mathrm{~kg} \mathrm{ha}^{-1}$ and grain yield ranging between about 700 and 1,200 $\mathrm{kg} \mathrm{ha}^{-1}$. For control treatments, simulated aboveground biomass and grain yield values were below $10 \mathrm{~kg} \mathrm{ha}^{-1}$, whereas observed values were somewhat higher. But since observed grain yields were less than $20 \mathrm{~kg} \mathrm{ha}^{-1}$, these treatments all represented crop failure. 
The output of the model in terms of rain water productivity as a ratio of dry matter or grain production to the amount of rain from planting to harvest was captured when compared to the observed data particularly for manure treated and control plots. This indicates that the measured data were adequately used to estimate the model parameters. The model calculates the amount of rain received during the cropping period based on weather data provided. Therefore this result could be expected as those two treatments were well simulated in terms of aboveground biomass and grain yield.

Water harvesting techniques are one of the means to combat desertification in sub-Saharan Africa. They are mostly used on the prevailing degraded bare land of the region. The results of the field study that served as the basis for model evaluation demonstrated that the zai technology is a powerful tool, which under extreme physical and chemical conditions, can substantially increase crop yield and provide conditions for crops to escape from adverse effects of dry spells. Even though zai technologies are indigenous in some countries, there is a need to extend them for broader use. A study for evaluating their effectiveness across environments is therefore needed because among the water harvesting technologies, the zai is simple and easy to implement by farmers as it requires locally-available material.

We contend that simulation analysis of these options can be used to provide insight on the effectiveness of alternative management systems. However, realistic inputs are needed for environments to be studied, and results must be interpreted relative to uncertainties in the inputs as well as limitations in the models. For example, the comparison of manure amendments in zai vs. flat planting, based on these results, could be simulated for a range of similar soils and climates with a reasonably high confidence level. However, simulating the use of lower quality amendments, particularly in similar highly degraded soils, would need to be interpreted in the context of limitations of the model. Although this is always true for model applications, the harsh conditions in this region make this an extremely important issue when conducting and interpreting results from such studies.

\section{References}

Adamou A, Bationo A, Tabo R Koala S (2007) Improving soil fertility through the use of organic and inorganic plant nutrient and crop rotation in Niger. In: Bationo A, Waswa B, Kihara J, Kimetu J, (eds) Advance in integrated soil fertility management in sub-Saharan Africa: challenges and opportunities. Proceeding of AfNet international symposium, Yaounde Cameroun, 17-21 Sept 2004. Springer, Dordrecht, pp 589-598

Agyare WA, Antwi BO, Quansah C (2008) Soil and water conservation in Ghana: practices research and future direction. In: Bationo A, Tabo R, Waswa B, Okeyo J, Kihara J, Fosu M, Kabore S (eds) Synthesis of soil water and nutrient management research in the Volta Basin. Ecomedia Ltd Publisher, Nairobi

Bado BV, Bationo A, Lompo F, Cescas MP, Sedogo MP (2007) Mineral fertilizers, organic amendments and crop rotation managements for soil fertility maintenance in the Guinean zone of Burkina Faso (West Africa). In: Bationo A, Waswa B, Kihara J, Kimetu J (eds) Advance in integrated soil fertility management in sub-Saharan Africa: challenges and opportunities. 
Proceedings of AfNet international symposium, Yaounde Cameroun, 17-21 Sept 2004. Springer, Dordrecht, pp 589-598

Bationo A, Christianson CB, Mokwunye AU (1989) Soil fertility management of pearl milletproducing sandy soil of Sahelian west Africa: the Niger experience. In: ICRISAT International Crop Research Institute for the Semi-Arid Tropics 1989. Soil, crop and water management systems for rainfed agriculture in the Sudano-Sahelian zone. Proceedings of an international workshop, 7-11 Jan 1987. ICRISAT Sahelian Center, Niamey, Niger

Bationo A, Sedogo MP, Buerkert A, Ayuk E (1995) Recent achievements on agronomic evaluation of phosphorus fertilizer sources and management in the west Africa semi-arid tropics. In: Ganry F, Campbell B (eds) Sustainable land management and African semi-arid and sub-humid region. Proceeding of the SCOPE workshop, Dakar, Senegal, 15-19 Nov 1993. CIRAD, Montpellier, pp 99-109

Bationo A, Rhodes E, Smaling EMA, Visker C (1996) Technologies for restoring soil fertility. In: Mokwunye AU, de Jager A, Smaling EMA (eds) Restoring and maintaining the productivity level of West African soils: key to sustainable development. IFDC-Africa, LEI-DLO abd SC-DLO, Miscellaneous Fertilizer Studies No. 14, International Fertilizer Development Center, Muscle Shoals (USA)

Bationo A, Mokwunye U, Vlek PLG, Koala S, Shapiro BI (2003) Soil fertility management for sustainable land use in the West African Sudano-Sahelian zone. In: Gichuru MP et al (eds) Soil fertility management in Africa: a regional perspective. Academy Science Publisher \& Tropical Soil Biology and Fertility, Nairobi, pp 253-292

Boote KJ, Jones JW, Bactchelor WD, Mafziger ED, Myers O (2003) Genetic coefficients in the CROPGRO-soybean model: links to field performance and genomics. Agron J 95:32-51

Buerkert A, Piepho HP, Bationo A (2002) Multi-site time trend analysis of soil fertility management effect on crop production in sub-Saharan West Africa. Exp Agric 38:163-183

Casenave A et, Valentin C (1989) Les états de surface de la zone sahelienne; Influence sur l'infiltration. Les processus et les facteurs de réorganisarion superficielle. (ed) ORSTOM Institut Français de Recherche Scientifique pour le Développement en Coopération. Collection Didactiques, Paris 1989, pp 65-190

Dzotsi KA (2007) Comparison of measured and simulated responses of maize to phosphorus levels in Ghana. MS thesis, Agricultural and Biological Engineering Department, University of Florida, Gainesville, 175 pp

Esse PC, Buerkert A, Hiernaux P, Assa A (2001) Decomposition and nutrient release from ruminant manure on acid sandy soils in the Sahelian zone of Niger, West Africa. Agr Ecosyst Environ 83:55-63

Fatondji D (2002) Organic amendment decomposition, nutrient release and nutrient uptake by millet (Pennisetum glaucum) in a traditional land rehabilitation technique (zai) in the Sahel. $\mathrm{PhD}$ Thesis, Ecological and Development Series No 1. Center for development research, University of Bonn, Cuvillier Verlag, Gottingen

Fatondji D, Martius C, Bielders C, Vlek P, Bationo A, Gérard B (2006) Effect of planting technique and amendment type on pearl millet yield, nutrient uptake, and water use on degraded land in Niger. Nutr Cycl Agroecosyst 76:203-217

Fatondji D, Martius C, Bielders C, Vlek P, Bationo A (2011) Effect of zai soil and water conservation technique on water balance and the fate of nitrate from organic amendments applied: A case of degraded crusted soils in Niger. In A. Bationo et al. (eds) Innovations as key to the green revolution in Africa, 1115 DOI 10.1007/978-90-481-2543-2_114

Gijsman AJ, Jagtap SS, Jones JW (2003) Wading through a swamp of complete confusion: how to choose a method for estimating soil water retention parameters for crop models. Eur J Agron 18:77-106

Godwin DC, Singh U (1998) Nitrogen balance and crop response to nitrogen in upland and lowland cropping systems. In: Tsuji GY, Hoogenboom G, Thornton PK (eds) Systems approaches for sustainable agricultural development; understanding options for agricultural production. Kluwer Academic, Boston, pp 55-77

Hassan A (1996) Improved traditional planting pits in the Tahoua department, Niger. An example of rapid adoption by farmers. In: Chris R (ed) Sustaining the soil. Indigenous soil and water conservation in Africa. Earthscan, London, pp 56-61 
Jones JW, Tsuji GY, Hoogenboom G, Hunt LA, Thornton PK, Wilkens P, Imamura DT, Bowen WT, Singh U (1998) Decision support system for agrotechnology transfer: DSSAT v3. In: Tsuji GY, Hoogenboom G, Thornton PK (eds) Systems approaches for sustainable agricultural development; understanding options for agricultural production. Kluwer Academic, Boston, pp 157-177

Jones JW, Hoogenboom G, Porter CH, Boote KJ, Batchelor WD, Hunt LA, Wilkens PW, Singh U, Gijsman AJ, Ritchie T (2003) The DSSAT cropping system model. Eur J Agron 18(3-4): 235-265

Mavromatis TK, Boote KJ, Jones JW, Irmak A, Shinde D, Hoogenboom G (2001) Developing genetic coefficients for crop simulation models with data from crop performance trials. Crop Sci 41:40-51

Naab JB, Singh P, Boote KJ, Jones JW, Marfo KO (2004) Using the CROPGRO-peanut model to quantify yield gaps of peanut in the Guinean savanna zone of Ghana. Agron J 96:1231-1242

Roose E, Kabore V, Guenat C (1993) Le“zaï": Fonctionnement, limites et amélioration d'une pratique traditionnelle africaine de réhabilitation de la végétation et de la productivité des terres dégradées en région soudano-sahelienne (Burkina Faso). - Cahier de l'ORSTOM, Serie Pedologie XXVIII (2):159-173

Schlecht E, Hiernaux P, Achard F, Turner MD (2004) Livestock related nutrient budgets within village territories in western Niger. Nutr Cycl Agroecosys 70:303-319

Sinaj S, Buerkert A, El-Hadjj G, Bationo A, Traore H, Frossard E (2001) Effect of fertility management strategies on phosphorus bioavailability in four West African soils. Plant Soil 233:71-83

Singh U, Ritchie JT, Thornton PK (1991) CERES-Cereal model for wheat, maize sorghum, barley and pearl millet. Agron Abstract 78

Singh P, Boote KJ, Yogeswara Rao A, Iruthayaraj MR, Sheikh AM, Hundal SS, Narang RS, Singh P (1994) Evaluation of the groundnut model PNUTGRO for crop response to water availability, sowing dates, and seasons. Field Crops Res 39:147-162

Sivakumar MVK, Maidukia A, Stern RD (1993) Agroclimatology of West Africa: Niger, 2nd edn. Information Bulletin 5. ICRISAT, Patancheru, $116 \mathrm{pp}$

Soil Survey Staff (1998) Keys to soil taxonomy, 8th edn. USDA/NRCS, Washington, DC

Sundquist B (2004) Land area data and aquatic area data; a compilation, 1st edn. March, 2004. http:/home.Alltel.net/bsundquist1/la0.html [checked 5.12.2005]

Tabo R, Bationo A, Gerard B, Ndjeunga J, Marchal D, Amadou B, Garba MA, Sogodogo D, Taonda JBS, Hassane O, Diallo MK, Koala S (2007) Improving cereal productivity and farmers' income using a strategic application of fertilizers in west Africa. In: Bationo A, Waswa B, Kihara J, Kimetu J (eds) Advance in integrated soil fertility management in sub-Saharan Africa: challenges and opportunities. Proceeding of AfNet international symposium, Yaounde Cameroun, 17-21 Sept 2004. Springer, Dordrecht, pp 589-598

Tsuji GY, Uehara G, Balas S (1994) Decision support system for agrotechnology transfer (DSSAT) v3. International Benchmark Sites Network for Agrotechnology Transfer, University of Hawaii, Honolulu

Willmott CJ (1981) On the validation of models. Phys Geogr 2:184-194

Yamoah CF, Bationo A, Shapiro B, Koala S (2002) Trend and stability analysis of millet yield treated with fertilizer and crop residue in the Sahel. Field Crop Res 75:53-62

Zougmoré R, Kambou NF, Zida Z (2003) Role of nutrient amendments in the success of half-moon soil and water conservation practice in semiarid Burkina Faso. Soil Till Res 71:143-149 